\title{
The effect of rootstock on the growth and yielding of 'Regina' cherry trees
}

\author{
Stanistaw Wociór \\ Department of Seed Science and Horticultural Nursery \\ University of Life Sciences in Lublin \\ Leszczyńskiego 58, 20-068 Lublin, Poland \\ e-mail: stanislaw.wocior@ar.lublin.pl
}

Key words: sweet cherry, rootstock, yielding, growth

\begin{abstract}
The studies conducted in the years $2004-2006$ in a production orchard in the habitat conditions of the Wyżyna Sandomierska showed that the trees budded on Mazzard seedling grew more strongly than on Colt rootstock. No significant differences were observed between the rootstocks as for the trunk thickness and the crown size of young trees planted in 2001. In the group of trees planted in 1996, which were in the period of full fruiting, the crowns of trees budded on Mazzard seedling were significantly bigger than on Colt rootstock. No significant differences were found in the yielding of trees grafted on Mazzard seedling and Colt rootstock. Considerable differences in the yielding between the studied years in the group of older trees point to a big influence of the weather on the fruiting of cherry. A significant decrease of the yield in 2005 was caused by spring ground frost, while in 2006 by frozen short shoots in winter. 'Regina' is a valuable cultivar for production planting in the Wyżyna Sandomierska. It begins the fruiting period late (the first commercial yield in the fifth year after planting); however, it gives
\end{abstract}


attractive fruits, resistant to cracking in the rain. 'Regina' yielded abundantly on both examined rootstocks.

\section{INTRODUCTION}

Sweet cherry is an excellent dessert fruit. The popularity of the cultivation of this species has grown increasingly, both in Poland and in the whole Europe (Makosz and Szafrańska 2006).

The shortcomings of sweet cherry are commonly known in science (Kemp and Wertheim 1996, Callsen 1998, Grzyb et al. 1998, Grzyb 1999, Grzyb et al. 2000, 2005, Rozpara 2000, Battistini and Battistini 2005, Stehr 2005) and in practice include very strong growth of the trees, failure in fructification and considerable sensitivity to frost.

Perry et al. (1996), Wertheim et al. (1998) and Webster (1998) believe that the worldwide program of estimating rootstocks under cherries undertaken within the last 10 years will bring more information on the usefulness in the planting practice of the accessible and new breeding material in different environmental conditions.

The purpose of the present studies was to estimate the growth and yielding of trees 'Regina' on two rootstocks in the area of the Wyżyna Sandomierska, known for mild climate.

\section{MATERIAL AND METHODS}

The studies were conducted in the years $2004-2006$ in a productive orchard belonging to Kazimierz Trześniewski and situated in Strączkowo of Samborzec commune. The experimental material included sweet cherry trees of 'Regina' budded on a vegetative rootstock Colt and Mazzard seedling. The trees were planted at the spacing of $5 \times 3 \mathrm{~m}$ on grey brown podzolic soil belonging to III valuation class with 'Kordia' as pollinator. The experiment was established in a scheme of completely randomized blocks. It included 4 combinations in 5 replications. The combinations were the trees grafted on Colt rootstock and on Mazzard seedling planted in the same orchard in the spring of 1996 and 2001. The repetitions were the plots where 3 trees grew on each.

The following measurements and observations were performed in the experiment.

In spring 2004 and autumn 2006 the trunk diameters were measured at the height of $30 \mathrm{~cm}$ above the ground. The diameter and height of the crowns were measured on the above mentioned dates. In the period of three years the yield from each tree was weighed and the fruits mass and the number of fruits cracking in the period of ripening was estimated on the basis of a sample of 100 fruits for 
replications. The area of the cross-section of the trunks, the cubic content of the crowns $\left(\pi r^{2} \mathrm{~h}^{-1}\right)$, the productivity of the trees and crowns as well as the percentage of fruit of lowered quality due to the cracking of the pericarp were calculated on the basis of the above mentioned measurements.

The results were statistically analyzed using variance analysis and Tukey's confidence intervals at the significance level of $5 \%$.

\section{RESULTS AND DISCUSSION}

In the conditions of the Wyżyna Sandomierska the trees budded on the Mazzard seedling grew more strongly than those on Colt vegetative rootstock.

In the case of young trees planted in 2001, the studies found out no significant differences between the rootstocks. The Mazzard seedling trees planted in 1996 had significantly thicker trunks than those planted on Colt rootstock only in 2004. Throughout the whole period of studies the crowns of this group of trees budded on Mazzard seedling were significantly bigger than on Colt rootstock. Similar results were obtained by Stehr (2005). Battistini and Battistini (2005) achieved greater strength of the trees' growth on rootstock SL 64 as compared to Colt. On the other hand, Perry et al. (1996) determined a considerably stronger growth of trees on Colt rootstock in comparison to Mazzard seedling and Saint Lucie cherry.

Table 1 presents the percentage of increasing dimensions of trees in the period of three years. It was demonstrated that in the case of young trees the increase of the trunk thickness and the crown dimensions in the period of three years was about twice as big as in older trees.

The studies on the size of the yield from a tree did not show any significant differences between the rootstocks for any age group.

'Regina' trees started the fructification period late on both rootstocks. Practically, the first commercial yield of about $5 \mathrm{~kg}$ from a tree was gathered only in the fifth year after planting. In the case of the trees planted in 2001 the yield significantly increased in each year. In the group of older trees a significantly higher yield was gathered in 2004 than in the other years.

Available literature provides differentiated results of estimating the effect of Colt rootstock on sweet cherry yielding. Grzyb et al. (1998) report that 'Burlat' gave more abundant yields on Colt rootstock as compared to Mazzard seedling, while 'Büttnera Czerwona' yielded worse in identical conditions on Colt rootstock. In the conditions of North Germany the yielding of 'Regina' on Colt rootstock was much worse than on the Mazzard seedling. In the conditions of the Wyżyna Sandomierska the studies demonstrated no significant differentiation of the yield of 'Regina' between the rootstocks either in young trees or in those that were at full fructification. 
Table 1. Influence of rootstocks on the growth of sweet cherry cultivar 'Regina' in 2004 and 2006

\begin{tabular}{|c|c|c|c|c|c|c|}
\hline & \multicolumn{2}{|c|}{$\begin{array}{c}\text { Trunk cross section } \\
\text { area in } \mathrm{cm}^{2}\end{array}$} & \multirow{2}{*}{$\begin{array}{c}\text { Increase } \\
\text { of } \\
\text { TCSA } \\
\text { in } \%\end{array}$} & \multicolumn{2}{|c|}{$\begin{array}{c}\text { Volume of crown in } \\
\mathrm{m}^{3}\end{array}$} & \multirow{2}{*}{$\begin{array}{c}\text { Increase } \\
\text { of crown } \\
\text { in } \% \\
\end{array}$} \\
\hline & 2004 & 2006 & & 2004 & 2006 & \\
\hline \multicolumn{7}{|l|}{ I. Trees planted in 2001} \\
\hline 1. 'Regina'/Colt & $19.3 c^{*}$ & $53.3 b$ & 276 & $1.3 \mathrm{c}$ & $5.5 \mathrm{c}$ & 423 \\
\hline $\begin{array}{l}\text { 2. 'Regina'/Mazzard } \\
\text { seedling }\end{array}$ & $22.7 \mathrm{c}$ & $66.7 b$ & 294 & $1.6 \mathrm{c}$ & $5.5 \mathrm{c}$ & 344 \\
\hline \multicolumn{7}{|l|}{ II. Trees planted in 1996} \\
\hline 3. 'Regina'/Colt & $166.9 \mathrm{~b}$ & $241.0 \mathrm{a}$ & 144 & $9.2 b$ & $16.7 \mathrm{~b}$ & 182 \\
\hline $\begin{array}{l}\text { 4. 'Regina'/Mazzard } \\
\text { seedling }\end{array}$ & $186.4 \mathrm{a}$ & $257.8 \mathrm{a}$ & 138 & $11.8 \mathrm{a}$ & $19.6 \mathrm{a}$ & 166 \\
\hline
\end{tabular}

*Means followed by the same letters do not differ significantly at $\mathrm{p}=0.05$

Table 2. Influence of rootstock on yielding of sweet cherry cultivar 'Regina' in $2004-2006$

\begin{tabular}{lcccc}
\hline & \multicolumn{3}{c}{ Yield per tree (kg) } & $\begin{array}{c}\text { Differences } \\
\text { between }\end{array}$ \\
\cline { 2 - 5 } & 2004 & 2005 & 2006 & the years \\
\hline $\begin{array}{l}\text { I. Trees planted in 2001 } \\
\text { 1. 'Regina'/Colt }\end{array}$ & $2.4 \mathrm{~b}^{*}$ & $5.1 \mathrm{~b}$ & $9.7 \mathrm{~b}$ & CBA** \\
2. 'Regina'/Mazzard & $1.8 \mathrm{~b}$ & $4.9 \mathrm{~b}$ & $9.6 \mathrm{~b}$ & $\mathrm{CBA}$ \\
$\quad$ seedling & & & & \\
$\begin{array}{l}\text { II. Trees planted in 1996 } \\
\text { 3. 'Regina'/Colt }\end{array}$ & $38.0 \mathrm{a}$ & $33.2 \mathrm{a}$ & $33.4 \mathrm{a}$ & ABB \\
4. 'Regina'/Mazzard & $36.6 \mathrm{a}$ & $32.0 \mathrm{a}$ & $32.0 \mathrm{a}$ & AAA \\
$\quad$ & & & \\
\hline
\end{tabular}

*Means followed by the same letters do not differ significantly at $\mathrm{p}=0.05$

**By the capital letters estimated differences between the years. The years with the same letters do not differ significantly at $\mathrm{p}=0.05$. 


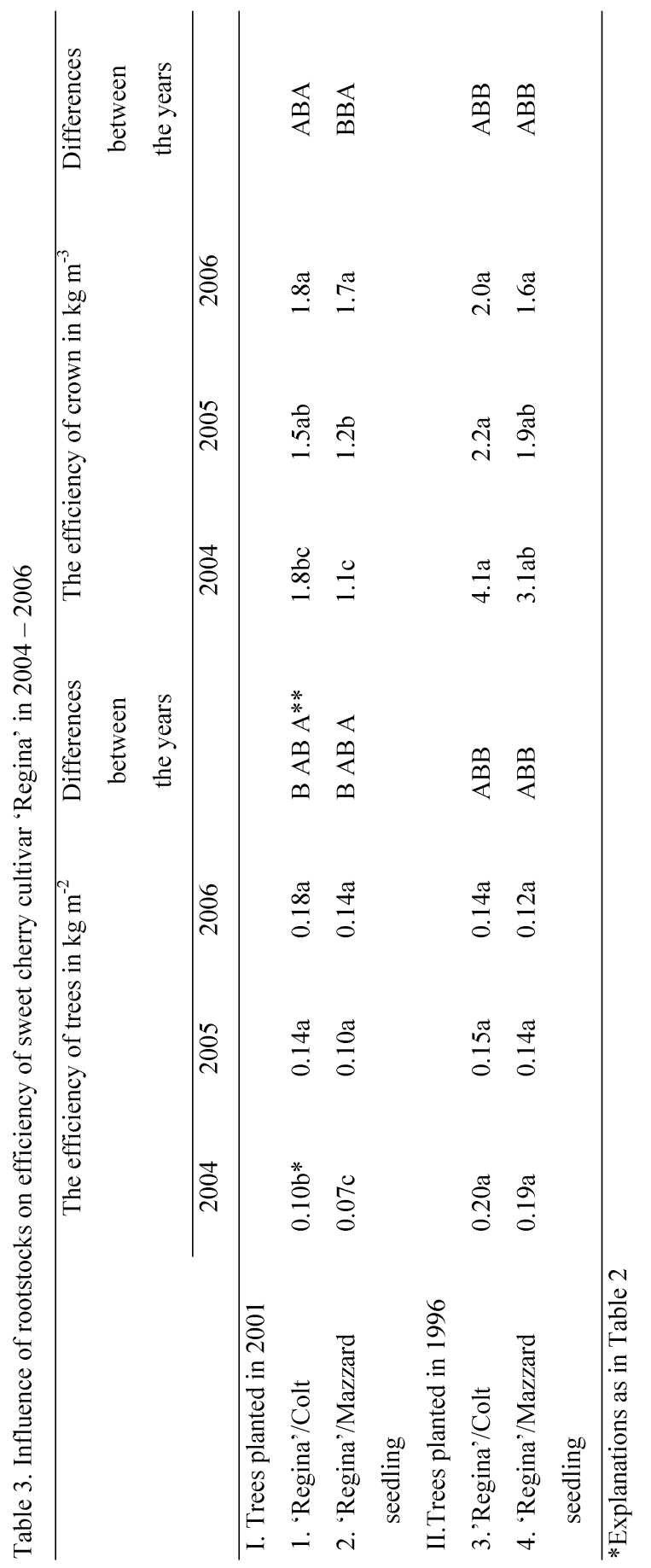


The productivity of trees and crowns on Colt rootstock was slightly bigger than on Mazzard seedling. Significant differences between the rootstocks were shown for young trees only in the first year. In the case of young trees a growing tendency was observed for productivity. The productivity of trees and crowns in older trees growing nearby in the same habitat conditions showed a decreasing tendency. In 2004 both parameters of estimation were much higher than in the other years. The observations of trees in the studied period make it possible to state that the basic cause of decreased yield and productivity in 2005 were the injuries of flowers brought about by spring frost in the lower parts of crowns. In 2006, when the temperature dropped to $-26.8^{\circ} \mathrm{C}$, injuries of the wood and the phloem on the short shoots of the trees were observed; nevertheless, the trees gave an abundant yield showing a slight decrease of productivity as compared to 2005 . Good regeneration of frost injuries seems a valuable feature of this cultivar.

In the years $2004-2006$ the fruits mass ranged from 8,2-8,9 $\mathrm{g}$ and the quantity of fruits bursting in the period of ripening cracking from 2 to $3 \%$. No significant differences were found between the rootstocks or the age groups.

\section{CONCLUSIONS}

- $\quad$ 'Regina' trees budded on Mazzard seedling grew more strongly than on Colt rootstock. No significant differences between the rootstocks were shown for the trunk thickness or the volume of the crowns of young trees planted in 2001. In the group of trees planted in 1996, which were at full fructification the crowns of trees budded on Mazzard seedling were significantly bigger than on Colt rootstock.

- $\quad$ Young trees increased trunk thickness and crown size about twice as fast as those at full fruiting.

- Under the examined conditions no significant differences in the yielding of trees on Mazzard seedling and Colt rootstock were found out. Considerable differences between the studied years in the group of older trees testify a big influence of the course of the weather on the fruiting of the cherry. A significant decrease of the 2005 yield was caused by spring ground frost, while in 2006 - by frozen short shoots in winter.

- 'Regina' is a valuable cultivar for production planting in the Wyżyna Sandomierska. It begins the fruiting period late (the first commercial yield in the fifth year after planting); however, it gives attractive fruits, resistant to cracking in the rain. 'Regina' yielded abundantly on both examined rootstocks. 


\section{REFERENCES}

BAtTistini A., Battistini G., 2005. Semi-dwarfing cherry rootstocks for dry condition. Acta Hort. 667: 89-190.

CALLSEN O., 1998. Recent developments in cherry rootstock research. Acta Hort. 468: 219-227.

GRZYB Z.S., 1999. Rola podkładki i wstawki w regulowaniu wzrostu i owocowania drzew czereśni. Zesz. Nauk. AR Kraków, 351, 66: 11-21.

GRZYB Z.S., SitAREK M., GuZOwSKA-BATKO B., 2005. Results of sweet cherry rootstock trial in Nothern Poland. Acta Hort. 667: 207-210.

GRZYB Z.S., SITAREK M., LIS J., 2000. Wzrost i owocowanie czereśni szczepionych na różnych podkładkach wegetatywnych. Roczn. AR Poznań CCCXXIII, Ogrodn. 31: 51-56.

GRZYB Z.S., SitAREK M., OMIECIŃSKA B., 1998. Growth and fruiting of sweet cherry cultivars on dwarfing and vigorous rootstocks. Acta Hort. 468: 333-338.

KEMP H., WERTHEIM S.J., 1996. First results of two international cherry. Acta Hort. 410: 167-176.

MAKOSZ E., SzAFRAŃSKA B., 2006. Przyszłościowy rozwój sadownictwa i szkółkarstwa sadowniczego w naszym kraju. „Przyszłość polskiego sadownictwa", Wyd. AR Lublin: 17-34.

PERRY R.L., RUNKEL J.L., LONGSTROTH M.A., 1996. The effects of rootstock on the performance of 'Hedelfingen' and 'Montmorency' cherry in Michigan, USA. Proc. Intl. Cherry Symp. Acta Hort. 410: 257-263.

ROZPARA E., 2000. Czereśnia. Zeszyty pomologiczne ISiK, Skierniewice.

STEHR R., 2005. Experiences with dwarfing sweet cherry rootstocks in Nothern Germany. Acta Hort. 667: 173-177.

WEBSTER A.D., 1998. Strategies for controlling the size of sweet cherry trees. Acta Hort. 468: 229-240.

Wertheim S.J., Balkhoven J.M.T., Callsen O., Vercamman J., Ystaas J., Vestrheim S., 1998. Results of two international cherry rootstock trials. Acta Hort. 468: 249-264. 


\section{WPŁYW PODKŁADKI NA WZROST I PLONOWANIE DRZEW CZEREŚNI ODMIANY 'REGINA'}

Streszczenie: Badania wykonane w latach 2004 - $2006 \mathrm{w}$ sadzie produkcyjnym w warunkach siedliskowych Wyżyny Sandomierskiej wykazały, że drzewa okulizowane na siewkach czereśni ptasiej rosły silniej niż na podkładce Colt. Nie wykazano istotnych różnic między podkładkami dla grubości pni i objętości koron drzew młodych sadzonych w 2001 roku. W grupie drzew sadzonych w 1996 roku, będących w pełni owocowania korony drzew okulizowanych na czereśni ptasiej były istotnie większe niż na podkładce Colt. W badanych warunkach nie wykazano istotnych różnic plonowania drzew na czereśni ptasiej i podkładce Colt. Znaczne różnice plonowania między latami badań $\mathrm{w}$ grupie drzew starszych świadczą o dużym wpływie przebiegu pogody na owocowanie czereśni. Istotne obniżenie plonu w 2005 roku spowodowały przymrozki wiosenne a w 2006 roku przemarznięcie krótkopędów w czasie zimy. 'Regina' jest bardzo wartościową odmianą do nasadzeń produkcyjnych na Wyżynie Sandomierskiej. Wchodzi ona dosyć późno w okres owocowania (pierwszy plon handlowy w 5 roku po posadzeniu), daje jednak atrakcyjne owoce, odporne na pękanie na deszczu. 'Regina' plonowała obficie na obydwu badanych podkładkach. 